\title{
Bridging Psychologies: Islam and Secular Psychotherapy
}

\author{
Samuel Bendeck Sotillos ${ }^{1}$ \\ Institute of Traditional Psychology
}

${ }^{1}$ Mental Health Therapist, Writer, and Researcher. E-mail: samuelbendeck@yahoo.com

Islamically Integrated Psychotherapy: Uniting Faith and Professional Practice Edited by Carrie York Al-Karam West Conshohocken, PA: Templeton Press, 2018, PP. 292.

Corresponding author: Samuel Bendeck Sotillos E-mail: samuelbendeck@ yahoo.com

eISSN: 2458-9675

Received: 17.04.2021

Revision: 29.04.2021

Accepted: 12.05.2021

CCopyright 2021

by Author(s)
Due to the lack of mental health services available to the Muslim community that are culturally and spiritually informed by the Islamic tradition, there has been significant stigma and misunderstanding about participating in therapy. This is in large part because modern Western psychology is commonly understood to be antithetical to Islam or any other religion or spiritual tradition for that matter. Although this has to some degree shifted in recent years with the increased awareness about the need for cultural and spiritual competencies within the field of mental health, it is still a problem.

What is not widely recognized by mental health professionals and the Muslim community is that there is a traditional "science of the soul" ( "ilm al-nafs) known as Islamic psychology. Islamic psychology is not about introducing religious terms or ideas into the preexisting structure of modern Western psychology, but rather a turn within the depths of the Islamic tradition itself, applying its own ontological and epistemic principles in understanding the human being and its relationship to the sacred and utilizing its own treatment modalities.

The dominant paradigms for studying the mind and behavior are in large part dependent on modern Western psychology and its exclusive ways of knowing that often discredit other modes of 
knowing. It views itself alone to be the only true psychology, yet it is in fact the only "science of the soul" that has divorced itself from the sacred. The notion that only modern science offers valid forms of knowledge is not only problematic, but hegemonic, and is rooted in the historical trajectory of the Renaissance, Scientific Revolution, and so-called Enlightenment. For Muslims around the world it is through the revealed and sacred book of the Qur'ān that one finds the source of all knowledge both outward and inward.

The editor of this volume, Carrie York Al-Karam, president of the Alkaram Institute, a nonprofit research and education institution, makes an important point about how prayer and increasing one's faith can be integral supports to an individual's mental health; however, she makes it clear that if there are serious concerns, individuals need to take appropriate actions to obtain professional help:

"Although the evidence suggests that prayer and other spiritual resources can be an incredible source of comfort during difficult times, religion and spirituality are not a cure-all. Failure to properly understand the complex and nuanced relationship between religion, spirituality, and mental health causes confusion and perpetuates stigma." (p. xiii)

This volume explores what is termed Islamically Integrated Psychotherapy (IIP), which integrates the tenets of Islam with those of modern psychology. Many Muslims are often reluctant to participate in mental health services, if they do not avoid participation altogether, if they are not contextualized within a spiritual framework, particularly that of Islam. This volume is a step in this direction as it is the direct application of the earlier book by Kenneth I. Pargament, Spiritually Integrated Psychotherapy, published in 2007 within the Islamic tradition.

This work consists of nine chapters, each presented by practicing Muslim clinicians conveying the way that they conceptualize the teachings, principles, and interventions of the faith to deliver culturally and spiritually appropriate services for the communities that they serve. The chapters have authors such as Abdallah Rothman, Layla Asamarai, Farah Lodi, Afshana Haque, Ibrahim Rüschoff and Paul M. Kaplick, Rabia Malik, Hooman Keshavarzi and Fahad Khan, Fyeqa Sheikh and Sayyed Mohsen Fatemi, each describing specific applications of IIP as they uniquely present themselves in individual, marital and family therapy, along with approaches for working with children and adolescents.

A key facet of this volume pertains to how individuals are challenged between living in accordance with the Islamic tradition and where this meets the challenges of the modern world that has divorced itself from the sacred. Through Islamic psychology individuals are provided with the transcendent principles that instill trust in God (Tawakkul), the remembrance of God (dhikr), and mindfulness or God-consciousness $(\operatorname{taq} w \bar{a})$, so that individuals can adequately face the trials and 
tribulations of the human condition, for they represent the many deaths of the false self or empirical ego in this temporal world (dunyā). The Qur'ān speaks of, "those who believe and whose hearts are at peace in the remembrance of God" (13:28) and says, "God tasks no soul beyond its capacity" (2:286).

What secular psychology often overlooks is that individuals tend to be confused about the meaning of their lives and do not know what they want or what is best for them. Islamic psychology, in contrast, explicitly acknowledges and addresses this confusion: "it may be that you hate a thing though it be good for you, and it may be that you love a thing though it be evil for you. God knows, and you know not" (Qur'ān 2:216). At the same time, every human being is responsible for their own actions: "No soul does evil, save against itself, and none shall bear the burden of another" (Qur'ān 6:164).

The purification of the soul (tazkiyat al-nafs) is of utmost importance as we are reminded: "Surely the soul commands to evil, save whom my Lord may show mercy" (Qur'ān 12:53). The perennial psychology, whether in the form of Islamic psychology or any other spiritual psychology, does not advocate suppression, but rather selfdomination over the lower tendencies of the human soul as informed by the sapiential traditions. Within Islamic spirituality, known as Sufism, there are four degrees of the human psyche ascending from the animal soul (an-nafs al-haywäniyah), the passional soul (an-nafs al-ammārah or "soul that incites" to evil), the discerning or intelligent soul (an-nafs al-lawwämah or "soul that blames"), and the intellective soul (an-nafs al-mutma 'innah or "the soul at peace," the human psyche reintegrated in Spirit or Rüh).

If the nafs (soul, self, or ego) is to be trained to resist desires, this is done not by opposing or suppressing them, as this can make them worse, for they can manifest in more unexpected or subconscious ways, becoming more subtle and difficult to detect. In the same way that the empirical ego cannot realize what is beyond itself, the nafs cannot resist the nafs through itself. This process requires the aid of a higher order of reality to transcend it; for this reason the participation in a spiritual tradition is vital. To conform to the desires of the nafs leads to the individual's destruction, and similarly to resist them leads to the Divine. From the earliest times, diverse human communities were instructed to conduct themselves accordingly: "So vie with one another in good deeds" (Qur'ān 2:148).

Without the inclusion of what transcends and integrates the human psyche into the Spirit, no psychotherapy can be effective. Likewise, any integral psychology requires the tripartite structure of Spirit/Intellect, soul, and body, known in Islam as Rüh/ 'Aql, nafs and jism. The role of cognition and behavior are central to Islamic psychology, yet they are situated in the sacred: "whosoever believes and makes amends, no fear shall come upon them, nor shall they grieve" (Qur'ān 6:48). Islamic psychology, including the perennial 
psychology, asserts the fundamental relationship between the human and the Divine in order to recover our primordial nature (fitrah). The Divine is both transcendent and immanent: "We are nearer to him than his jugular vein" (Qur'ān 50:16). For this reason, a hadìth emphasizes that "He who knows himself knows his Lord."

When receiving mental health services in this culturally and spiritually informed manner, the individual is continuously aware that while the mental health professional is there to provide treatment, it is ultimately the Divine alone that imparts true therapy. As the Qur'ān points out: "And when I am ill, it is He Who cures me" (26:80). This does not mean that the therapist's role is minimized or unimportant. Here the therapist has knowledge of and experience in supporting and providing treatment, yet they are also aware of their own limitations and that they too are on the spiritual path as is the individual receiving services. It is God alone who can truly heal. It is also important to note that across all of the diverse communities (ummah) of the world, each has its own way of leading the seeker back to the Divine, as has been emphasized: "And for every community have We appointed a ritual" (Qur'ān 22:34).

This volume will be welcomed and is valuable for Muslims and Muslim clinicians along with general mental health professionals who are interested in spiritually integrated psychotherapy as it applies to the Islamic tradition. Although modern psychology has begun to some degree to incorporate religious and spiritual practices into its secular framework and is becoming more open to these approaches, it still has a long history of pathologizing religion and spirituality. Additionally, modern Western psychology still in large part views itself as the only valid psychology, implicitly refuting the idea of the existence of other psychologies. This is a very problematic situation that has not been fully understood and cannot be remedied until it is addressed.

While one can certainly find common ground between the spiritual psychologies and that of modern psychology, no integration between the two is possible without first examining their foundations for inherent conflicts. The important question remains: Is modern psychology able to acknowledge the existence of the sacred? Again, the foundations of modern psychology are secular, which means they are cut off or divorced from the sacred. Because of this exclusion of the sacred, one must ask how modern psychology can ever be a true "science of the soul." It cannot be minimized that the emergence of modern science and its psychology was an all-out assault on the metaphysical roots known across the sapiential traditions. The very foundations of contemporary psychology begin with the movements of psychoanalysis (Sigmund Freud, 1856-1939) and behaviorism (John B. Watson, 1878-1958; and B.F. Skinner, 1904-1990), which both constitute the structure of modern psychology. All of the movements and schools that came after them can be viewed as continuations in one form or another of these two pioneering forces, which have not as many assume disappeared 
into the annals of history. The question that begs to be answered is whether modern psychology or the field of mental health as it is known today be truly extricated from this superstructure? Malik Badri cautioned in 1979 about adapting the tenets of modern psychology to that of the Islamic tradition and urged the revival Islamic psychology to be a discipline distinct from modern psychology; others have also advocated for this separation and provided valuable articulations of the goal of rehabilitating the traditional "science of the soul" as it was known in all times and places (Nasr, 2007).

If Islamic psychology or other forms of perennial psychology are going to be taken seriously and made available on a large scale, the limits and challenges pertaining to modern Western psychology need to be recognized and remedied. However, it is necessary to emphasize that no form of perennial psychology requires a stamp of approval from modern Western psychology or its science; it receives its validation and efficacy alone through its own metaphysics, sacred science, and spiritual principles that inform its "science of the soul." According to Islamic psychology, "God alters not what is in a people until they alter what is in themselves" (Qur'ān 13:11) and, according to a prophetic saying, "for every disease there is a cure."

\section{References}

Badri, M. (1979). The dilemma of Muslim psychologists. MWH London.

Eaton, C. L. G. (2008). The book of hadith: Sayings of the prophet Muhammad from the Mishkāt al-Mașabih. Book Foundation.

Nasr, S. H. (2007). The integration of the soul. In W. C. Chittick (Ed.), The essential Seyyed Hossein Nasr (pp. 73-84). World Wisdom.

Nasr, S. H., Dagli, C. K., Dakake, M. M., Lumbard, J. E. B., \& Rustom, M. (Eds.). (2015). The study Quran: A new translation and commentary. HarperCollins.

Pargament, K. I. (2007). Spiritually integrated psychotherapy: Understanding and addressing the sacred. Guilford Press. 